\title{
Modelling farmers' action: decision rules capture methodology and formalisation structure: a case of biomass flow operations in dairy farms of a tropical island
}

\author{
J. Vayssières ${ }^{1 \dagger}$, P. Lecomte ${ }^{1}$, F. Guerrin ${ }^{2}$ and U. B. Nidumolu ${ }^{1}$ \\ ${ }^{1}$ Centre de Coopération Internationale en Recherche Agronomique pour le Développement, Département Elevage et Médecine Vétérinaire, Pôle Elevage, Station de \\ Ligne Paradis, 7 chemin de I'Irat, F 97410 St Pierre, île de la Réunion, France; ${ }^{2}$ Centre de Coopération Internationale en Recherche Agronomique pour le \\ Développement, Département Cultures Annuelles - Institut National de Recherche Agronomique, Unité propre de recherche Risque Environnemental du Recyclage, \\ BP 20, F 97408 St Denis Messag Cedex 9, île de la Réunion, France
}

(Received 6 October 2006; Accepted 4 January 2007)

Studies on decision-making processes are generally aimed at identifying farmers' needs and predicting farmers' reactions to technical innovations. In the present paper we study these decision-making processes, with reference to dairy farms, to build a whole-farm computer model (WFM) which simulates farmers' actions. In this study, (i) a multi-tool and multi-step methodology is proposed, which can also be qualified as an iterative and interactive methodology to reveal decision rules and (ii) a generic structure to formalise how action is conducted, termed 'structure for action modelling' (SAM). In the case of forage crop-dairy cattle systems, we have tested the current methodology to capture the decision rules and the SAM to represent action concerning farm management. An 'immersion' approach, inspired by the ethnographic approach has been adapted to access operational technical decisions (taken on a daily basis). This study helped in understanding how detailed and large approaches can be complementary and can facilitate identification of what can be generalised in a conceptual model. To define the generic structure $(S A M)$, a set of descriptive variables concerning technical operations has been selected. The conceptual model generated is composed of decision rules reconstructed by researchers with farmers' committed participation. The validation method is based on participatory approaches and on comparing of actions simulated by the model with practices on the ground. Not contesting the fact that farmers plan their action, this study also revealed the importance of adjustments in action. For example, 20 to $55 \%$ of the time the planned food ration is not distributed to the milking cows because of forage unavailability. We also discuss how this structure can facilitate integration of decision mechanisms in biophysical models and how such an integration of adjustment decision rules can produce more realistic simulations of technical actions. Error of biotechnical evaluations done by the WFM is reduced from about $25 \%$ to about $10 \%$ with the application of the proposed method.

Keywords: dairy farming, farm management, decision making, simulation models, technical operations

\section{Introduction}

During the second part of the last century, a number of studies were been undertaken to define techniques or models to improve technical and economic performance of farms. However it is often seen that farmers do not follow the technical advice of the extension services. For example, Sumberg (2002), cites the case of livestock nutrition, and underlines that African producers have shown little interest in improved food technologies. Aubry et al. (1998) and Aubry (2000) cite similar case studies on crop systems

\footnotetext{
${ }^{\dagger}$ E-mail: jonathan.vayssieres@cirad.fr
}

(Spedding, 1975; Ruthenberg, 1980; Collinson, 1983). It is now widely acknowledged that such poor application of advice is not simply due to the technical failings of the farmers. Farmers' practices reflect their particular aims and constraints (Sebillotte, 1979; Capillon, 1986). Understanding the reasons for these practices is now regarded as a necessary step towards designing new agronomic production techniques (Sebillotte, 1987; Gibbon, 1994). According to Thornton and Herrero (2001), the likely trends of smallholders crop-livestock systems development within the next 20 to 30 years will require models to enable analysis of those complex systems, assess their impact, and help farmers to improve their performance. These 
observations justify farming systems and decision-making process research (Aubry et al., 1998; Aubry, 2000).

It is now widely assumed that computer models can be used to support farmers' decisions. However, most of these decision-support systems are optimisation-based models that are mainly used as recommendation and prescriptive models: responding to 'How-to questions?' (Mc Cown, 2002). Computer models can be constructed with other objectives such as: representing farmers' practices and simulating technical alternatives with participation of farmers (Attonaty et al., 1999). These simulation models respond to 'What if?' questions (Mc Cown, 2002). The authors argue that this approach is more likely to foster interactive reflection and discussions among stakeholders about their own practices.

As discussed by Cros et al. (2001), one way to represent effective practices can be to develop a decision system linked to the biophysical system (composed by purely biophysical models). But the basic question is how can the decision system be structured to link it to the biophysical system? Farmers' actions constitute the material and conceptual link between their decision processes and their control on the biophysical processes. Hence, technical operation could be considered as a central concept of models that have to represent farmers' practices. A technical operation constitutes an elementary action or a group of elementary actions (always performed together), realised by the workforce of the farm, that have well defined effects on the different production processes of the farm.

A dairy farm system can be represented as a biomass cycle and within such system, two types of material flows are distinguished: those mainly driven by human agents: actionable flows, and those mainly driven by natural causes: biophysical flows. Previous studies by the authors (Vayssières et al., 2003 and 2004) have shown that most of biomass flows in dairy production systems are actionable flows. There are 19 technical operations that generate biomass flows on the farm listed in Table 1. This type of flow is called 'biomass flow operations'. All these operations have been considered in this study (Vayssières, 2004). Hence, a dairy farm system can be defined as the management of temporal variability of biomass stores and flows to improve economic returns, to reduce labour stress and environmental impact. Moreover, the term of 'farm management' is used here to describe the ways in which a farmer obtains, stores, uses and distributes, the biomass, originating from his own farm or other farms, over time and space.

The aim of this paper is to propose a method to study and represent technical decisions for action modelling. The first hypothesis is that the action plan is not sufficient to simulate the realism of management actions. The second

Table 1 Main realisation constraints expressed by farmers to realise the 19 technical operations that generate biomass flows

\begin{tabular}{|c|c|c|c|}
\hline Action domain & Technical operations & Main constraints & Priority \\
\hline \multirow[t]{4}{*}{ Forage surface management } & Silage making in wrapped bales & $\begin{array}{l}\text { Rain, equipment downtime and breakdown, } \\
\text { high cost }\end{array}$ & 7 \\
\hline & Green grass harvest & $\begin{array}{l}\text { Workforce insufficiency, daily mandatory work, } \\
\text { variability of grass growing speed, rain }\end{array}$ & 3 \\
\hline & $\begin{array}{l}\text { Green canes harvest (sugar and } \\
\text { forage cane) }\end{array}$ & $\begin{array}{l}\text { Workforce insufficiency, work onerousness, daily } \\
\text { mandatory work, rain }\end{array}$ & 4 \\
\hline & Changing of pasture (rotation) & Rain, heat & 8 \\
\hline \multirow[t]{2}{*}{ Feed management } & $\begin{array}{l}\text { Concentrated feed buying (concentrate, } \\
\text { molasses, milk powder, etc.) }\end{array}$ & High cost & 13 \\
\hline & $\begin{array}{l}\text { Forage buying (cane straw, bagasse, } \\
\text { hay, etc.) }\end{array}$ & $\begin{array}{l}\text { Low availability, storage difficulties, high } \\
\text { cost }\end{array}$ & 15 \\
\hline \multirow[t]{6}{*}{ Herd management } & $\begin{array}{l}\text { Feeding of different animal batches } \\
\text { (calves, heifers, dried up cows, } \\
\text { producing cows) }\end{array}$ & $\begin{array}{l}\text { Variability of forage availability, acidosis } \\
\text { risks }\end{array}$ & 2 \\
\hline & Heifers buying & High cost, sanitary risks & 16 \\
\hline & Calves sale & - & 17 \\
\hline & $\begin{array}{l}\text { Voluntary culling of animals } \\
\text { (DC or heifers) }\end{array}$ & $\begin{array}{l}\text { Lack of heifers, to much sustained scrapping, } \\
\text { demand variability }\end{array}$ & 18 \\
\hline & Milking & Daily mandatory work & 1 \\
\hline & Mulching & Low availability and high cost of sugar cane & 5 \\
\hline \multirow{7}{*}{ Fertiliser management } & Slurry removal & Work onerousness & 6 \\
\hline & Solid manure removal & Work onerousness & 12 \\
\hline & Mineral fertiliser buying & High cost & 14 \\
\hline & Mineral fertiliser spreading & High cost & 11 \\
\hline & Slurry spreading & Rain, field impracticability, workforce insufficiency & 9 \\
\hline & Solid manure spreading & Rain, field impracticability, workforce insufficiency & 19 \\
\hline & Solid manure sale & High offer and low price & 10 \\
\hline
\end{tabular}


hypothesis is that one methodological approach will not be sufficient to capture the decision rules. We take an example of dairy farm management and illustrate our approach on two management operations in the scope of responding to these resulting questions: 'Do the dates of ensiling works and the ration composition correspond to the action plan or do supplementary decision rules have to be captured to simulate more realistic management actions?' and 'How to access farmers' reasoning about farm management and to capture their decision rules while not being limited to a basic action plan description by farmers?'.

\section{Material and methods}

\section{Literature review}

General concepts to define the domain of the present study. Researches on production systems are based on two principles. The first considers a farm as a complex system with many components that interact. The second is the farmer's rationality principle. Farm functioning and farming practices are seen as the result of a farmer's direct intentions. To analyse them, one must look at the underlying decision-making processes, which acts as 'a sort of driving force for the practices' (Papy, 1994).

Strategic, tactical and operational decisions are classically distinguished (Fountas et al., 2006). The distinction is based on the temporal horizon of the decision. Strategic decisions have a multi-year horizon (long term), the horizon of tactical decisions is limited to the yearly campaign (medium term) and the technical decisions are made on a daily basis (short term).

Structural and technical decisions are also classically differentiated. Structural decisions are strategic decisions. They represent production choices (e.g. dairy or meat cattle) and productive resources gathering (land, workforce, equipment, buildings, etc.) that constitute the production system. Technical decisions are taken to manage the production system. They concern resource allocation to technical operations (Papy and Mousset, 1992).

In this article we consider only technical decisions in general and operational decisions in particular.

Conceptual decision models resulting from the concept of action model. An 'action model' is a conceptual representation of a farmer's practices, composed of (i) one or several general objectives that guide the farmer's technical decision making; (ii) an anticipated action plan including a forward-planning schedule organising these decisions in time and the way it is hoped operations will unfold; and (iii) a set of decision rules (holding for each stage of the plan) and indicators designed to make sure the desired plan is adhered to (Duru et al., 1988; Sebillotte and Soler, 1988 and 1990; Papy, 1994). This conceptual representation proposes distinguishing two types of operational decision rules: the realisation decision rules that determine how action is usually made, and adjustment decision rules that facilitate alternative actions.

This approach has been used successfully for representing the management of annual crops (Aubry et al., 1998; Dounias et al., 2002), perennial crops (Bellon et al., 2001), grazing (Cerf et al., 1990; Duru et al., 1990), animal waste (Aubry et al., 2006) and resources such as labour (Attonaty et al., 1993) or irrigated water (Le Gal and Papy, 1998). In the present study, we apply this concept at the whole-farm level, considering both crop and livestock production subunits, with special consideration of animal management operations.

Most of those previous studies have shown that farmers plan their cyclical (recurrent) technical operations and that one can model this planning process (Aubry et al., 1998; Le Gal and Papy, 1998; Dounias et al., 2002). These studies propose a conceptual decision model explaining how farmers define and decide their planning schedules. We propose here to generalise it to decisions behind actions. We shall therefore propose building a model including:

- descriptive variables of the technical operations, i.e. the elements the farmer must decide upon in order to do action;

- decision rules that lead to these variables.

Agricultural production systems ontology. An ontology is a modelling framework. As in industrial systems (Uschold et al., 1997), agricultural production systems can be divided in three subsystems: the manager, the operating system and the biophysical system (Martin-Clouaire and Rellier, 2000).

The biophysical system formalises global farm structure and is the place of production processes. It is composed of biophysical entities that usually have their own processes (e.g. plant development, animal productions such as milk or faeces). Some of these processes are biomass flows. Among the events controlling these processes are those resulting from the operations executed by the operating system (Martin-Clouaire and Rellier, 2000).

The manager who is typically the farmer is the system responsible for achieving the overall production system objectives. To this end, it possesses a management strategy that drives the behaviours of the operating system and indirectly of the biophysical system. In the ontology, strategy does not hold the same significance for the agronomists, as it corresponds to their action model. The management strategy specifies the flexible organisation of the intended operations (nominal plan), their implementation requirements and the conditional self adaptations that should take place when particular events occur. This subsystem generates, among others, the candidate sets of operations that are feasible (= to be considered).

The operating system is in charge of transforming the manager's advocated sets of operations (all or a part of the operations) into an executable set of operations in compliance with the requirements communicated by the 
manager. Its unique component is the resources pool. The operating system has then to execute the operations in compliance with the requirements communicated by the manager, the resources availability and the state of the production system environment. Resources (e.g. labour, biomass stores, etc.) are elements of the production system that are necessary and mobilised for the operations realisation (Martin-Clouaire and Rellier, 2000). In this study, we consider that the decision system contains both the manager and the operating system.

Martin-Clouaire and Rellier (2003) defined an ontology for managed systems applied to agricultural production. Relevant terms to represent the decision system of our model have been selected from this ontology and these terms are presented in this section.

In accordance with the subdivisions of the production system, the operations are in the first instance advocated (= suggested) by the decision system, then the operating system specifies each operation, i.e. it activates and characterises them regarding the state of the biophysical system and its environment. It may happen that conditions are not favourable and that, as a consequence, some advocated operations are not realised.

(1) Advocating process: the operations advocating obeys starting rules. Those rules are elements of the manager. They are associated with two information types.

- Alarms informing on the production system state in reference to an indicator. For example the level in a slurry pit exceeding $90 \%$ of the storage capacity puts the operation 'slurry spreading' in the set of feasible operations.

- Operations schedule defining directly the rhythms and the periods of advocating. For example the milking has to be performed twice daily. This schedule corresponds to the timing part of the action plan of the model for action.

(2) Specification elements: one operation is characterised by two resources among others - the performer, the author of the operation and the operated object, object of the operation as its name indicates.

(3) Specification rules: the strategy also contains a set of specification rules for management operations.

- Some priority rules. Those priorities concerned with resources or operations. The operations priority rules guide the operating system for the constitution of the set of operations to be realised. The resources priority rules attribute to operations one resource more than others when a choice is possible.

- Some constraints of operation realisation.

This ontology has been conceived from the survey of indoor tomato cropping. This production system is specific and is not so far from industrial systems. Indeed, this production is relatively free from climatic risks and it supposes an abundant labour-force with different hierarchic decision levels. We propose here to venture outdoors, to use this conceptual model to represent the way farmers manage a whole farm, and to transfer those approaches to represent action in an animal-dominant production system.

\section{Study area description}

Reunion is a volcanic island of $2500 \mathrm{~km}^{2}$, with $40 \%$ of its area located above $1000 \mathrm{~m}$ of altitude and two-thirds with slopes above $10 \%$. The general agricultural context of the island has been described by Aubry et al. (2006). Sugar cane is the main crop ( $59 \%$ of the agricultural land) and is located in the lowlands. Dairy farms are distributed in the highlands (between 500 and $1600 \mathrm{~m}$ of altitude). Pedo-climatic conditions are very variable over the island linked to relief and altitude, producing important vegetation diversity. The main forage crops cultivated are chloris (Chloris gayana), sugar cane (Saccaharum officinarum), forage cane (Pennisetum purpureum) under $800 \mathrm{~m}$ of altitude. Over this limit kikuyu (Pennisetum clandestinum), dactyle (Dactylic glomerata), ray-grass (Lolium multiflorum and Lolium hybridum) and brome (Bromus catharticus) are cultivated (Barbet-Massin et al., 2004). The Reunion climate is tropical with oceanic influence due to exposure to the trade wind. The eastern part of the island is exposed to trade wind and is humid ( 3000 to $6000 \mathrm{~mm} / y e a r$ ), whereas the western part, protected by the central mountains, receives less than $1000 \mathrm{~mm} /$ year. Two main seasons can be distinguished (with short transitions) (i) a rainy and hot period: the summer from October to May, and (ii) a dry and cold period: the winter season from June to September.

The dairy sector in Reunion is recent and has seen significant development since the end of the 1980s. This development responds to the local demand with the increased purchasing power, the changing consumption patterns, and the population growth. In 2003, the total local production was 22 million litres (135 farms). This production is largely under the production allowed by the global quotas attributed to the island (40 million litres). The milk is produced by about 4000 cows. The farm surveyed by the 'milk control' had an average productivity of $5750 \mathrm{~kg} /$ year per cow in 2003. The milk control is a service (partially financed by the Regional Authority) periodically giving (every 45 days) technical characteristics of the dairy cattle (milk production, reproductive performance, milk composition, etc.) to help farmers manage their farm. All the 135 farms are members of the only Dairy Cooperative on the island. The milk locally collected represents $30 \%$ of the consumption of the island. The rest of the demand is covered by powder and cheese imports. Reunion agricultural policy has developed its dairy farming sector in order to increase its self-sufficiency in milk, to preserve agricultural employment and rural population in highlands.

Methodology: an iterative combination of approaches to revel decision rules

Real-world cases are studied, building up a methodology based on three complementary types of inquiries per farm: 
immersion, visits and meetings. A special group of six farmers called the 'working group' was involved in those three types of inquiry.

Immersion. Detailed research was conducted by sociologists, such as Becker (1963) and Dodier (1995), by living the life of their subjects. In agreement with the work of Lawas and Luning (1996), immersion was retained with the aim of revealing operational decisions taken on a daily basis. Immersion is an original method for technical data gathering. It is based on 1-week work-cum-training periods including open discussions with the farmer (Vayssières, 2004). The researcher directly participates in the technical operations of the farm under the direction of the farmer. This particular rapprochement creates a confident atmosphere and offers many opportunities for action observations. A period of about 8 weeks was spent by the first author of this paper in immersion on dairy farms.

This study on dairy farmers' technical decisions at a farm scale is new for Reunion Island. Living farmers' lives was also a good opportunity to realise the questions and constraints of farmers on a daily basis and for improved definition of the hypothesis of this study.

The main result of this type of inquiry was six monographs and action models (of these six farm cases included in the working group). The household and farm chief's objectives, the production objectives and the action plan were identified well; however, adjustment rules were incomplete. It was realised later that only more common operational decision rules were expressed by farmers. It was difficult for them to consider all the cases as the inquiries were localised in time. Farmers could have forgotten some adjustment rules, hence bimonthly visits were organised.

Inquiries and observations within the scope of bimonthly visits. In tune with the experiences of Aubry et al. (1998) and Dounias et al. (2002), we organised regular visits to the farmers about the planning of their technical operations, their effective practices and the technical results of their actions (to quantify biomass flow). We have collected those data on a bimonthly basis over 2 years. The first author of this paper continued to participate in the farm works to maintain the especially confident relationship.

The principal objective of this second type of inquiry was to compare regularly (six times per year) with farmers their action plan to their effective actions (plan versus reality). We used farm management schedules as discussion supports. Environmental conditions (weather, fodder market, etc.) were recorded and some observations were made on the grass fields and the cattle, so as to be able to describe operating conditions. Many complementary operational rules, adjustment rules in particular, were identified.
Individual and collective validation from farmers themselves. Three types of validation contexts have been coupled: individual feed-backs in the scene of the bimonthly visits, collective feed-backs and collective work during meetings. These meetings were organised three times per year on each of the farms of the working group. It was an occasion for the farmers to present their farm and their practices to the others. This idea came from a particularly active farmer. The reason expressed was 'we do not like to be in offices and it is an opportunity to see farms from other areas'. It was a sort of 'spontaneous farming field school'.

Each individual model for action was individually and collectively presented (both by farmers and a researcher) and discussed. The experience has shown that it is difficult to speak about operational rules during a meeting, and that individual feed-backs are more adapted to validate these types of decision rules. Most corrections have resulted from individual feed-backs. But it was important to verify if the farmers' discourses changed from private talk to public expression and it was realised that there was no significant change and it is seen as a sign of validation in the current study.

A brainstorming session was organised, with the working group consisting of the six farmers, to select the key management points. Topics such as 'to produce liquid manure, solid manure or compost?', 'to feed cows with bought or on farm produce food?', 'pasture, green reap or ensilage?' were discussed and this led to improved understanding of reasons of the technical choices.

The method presented above was applied for 3 years on each of the chosen farms. Working during 3 years with only six farmers needed to have careful consideration of the definition of this working group.

Definition of the working group based on an iterative process. The definition of the working group has been an important question. The objective was to select less than 10 farmers - a small number dictated by the timeconsuming nature of our methodology - to represent the diversity of the management strategies. One technicaleconomical typology had been carried out earlier in the same region (Alary et al., 2002). The first sample was composed of six farms chosen to have one farm per type and per dairy cattle-rearing area. For this occasion, five areas were defined with agricultural technicians (Vayssières, 2004). We also requested the agricultural technicians to validate this first sample of six farms to represent the diversity of management styles (Figure 1).

A first series of immersions $(-1-)$ was conducted on the six farms producing six action models. During individual feed-backs many discussions were stimulated on the content of the action models (farmer's objectives, action plans, adjustment rules). Therefore we identified a series of management key points concerning key technical operations (described below). These points later helped in the formulation of a rapid appraisal that was administered on 


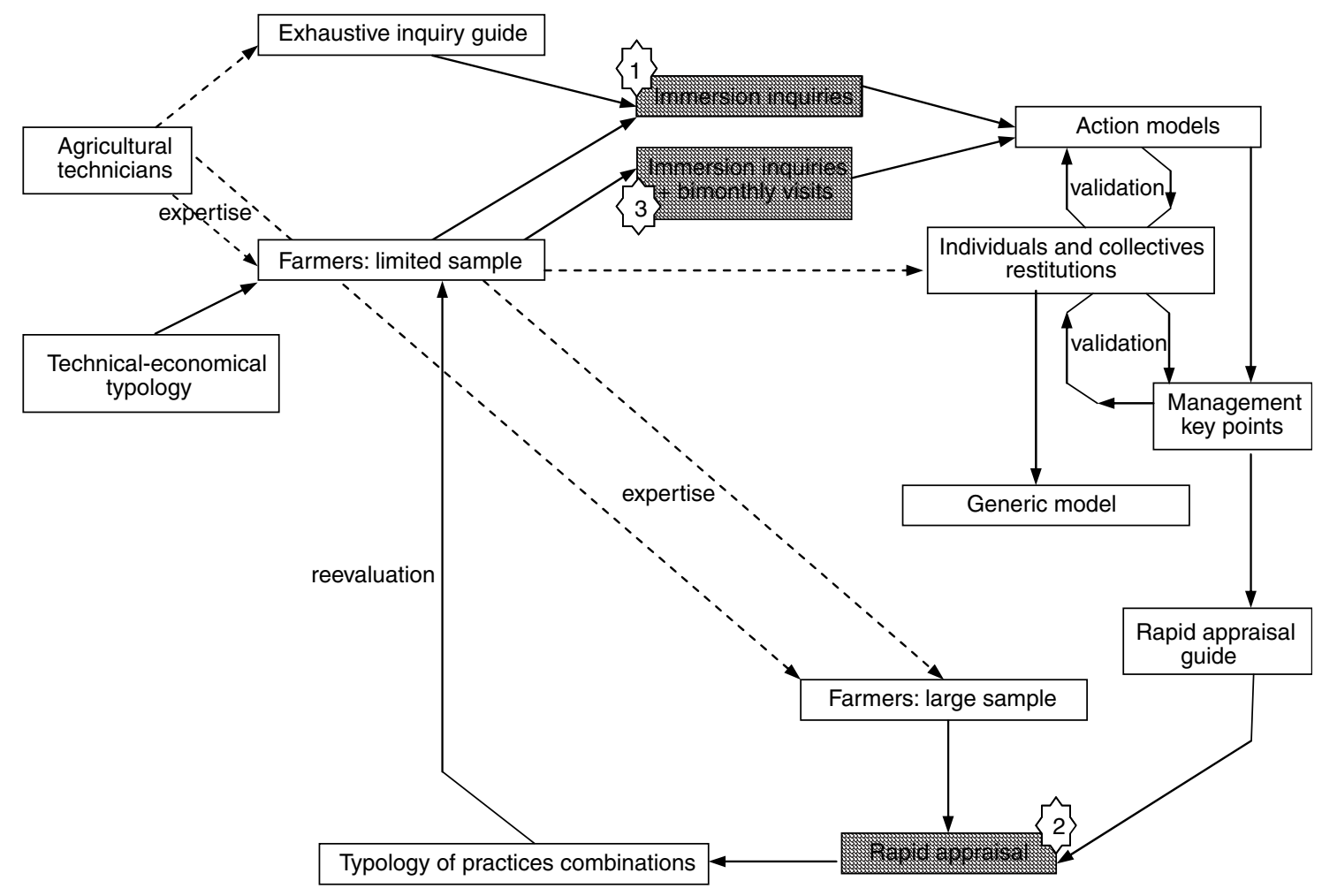

Figure 1 The multi-approaches methodology to capture decision rules represented as an information gathering cycle.

a larger sample of farmers to evaluate the first sample of six farmers.

The farmers of the first limited sample were mobilised in the definition of the large sample. 'From your point of view, which farms have to be visited to cover the different ways of farm management?' has been asked of the first six farmers. They decided to introduce five to seven farms in each of their area. A total of 36 farmers were selected and were interviewed about their management practices and their household objectives (-2-). A typology (five types for the 36 farmers) which was defined by a combination of practices of farm management was developed (Vayssières et al., 2006). It was then possible to re-evaluate the first limited sample of six farmers. Four of the five types of 36 farmers were represented in the first limited sample of six farmers. Hence, a complementary immersion $(-3-)$ was conducted with a farmer (falling in the fifth type) in the sample of 36 farmers.

Complementarities of immersion and rapid appraisal. The methodology presented above should not be considered as rigid and flexibility in use is required.

We argue that immersion and rapid appraisal are complementary. Immersions provide insights into intricacies of farming systems and it is essential to understand such complex systems such as crop-livestock production systems. But its specificity and illustrative nature mean that generalisation may be limited. Outputs from detailed studies have been important pre-requisites for the larger approaches (covering more than 30 farms) and should therefore be used in conjunction with other larger analysis.

Rapid appraisal was not only conducted to evaluate the representativeness of the real cases studied but also to compare the results of the methodology proposed in this paper (including immersion) to the results of a more classical rapid appraisal. Rapid appraisal is adapted to define the action plan of the farmer. The detailed studies offer the opportunity to define the operational decision rules presented in the general structure for action modelling (the SAM) proposed below.

Validation by simulating farmers' actions. A whole-farm model (WFM) has been developed using VENSIM ${ }^{\circledR}$ dynamically to represent the functioning of the farm. Based on the studies of Cros et al. (2001), this computer model comprises of two sub-systems: the whole-farm biophysical system (WFBS) and the whole-farm decision system (WFDS). The WFBS is constructed by merging different functions or parts of the existing biophysical models of the literature (e.g. Jarrige (1988); Fox et al. (2004) for the milk production sub-model). The WFDS is relevant to the current article while WFBS is beyond the scope of this paper.

The WFDS construction is based on the SAM and the decision rules identified with the chosen methodology. Two options have been simulated with the current WFM: (i) simulation of the 'planned actions': this simulation is based on the action plan of the farmer; (ii) simulation of the 'SAM actions': this simulation is based on the 
operational rules: both realisation and adjustment rules are structured in the SAM. To validate the chosen approach 'planned actions' and 'SAM actions' have been compared with 'effective actions' observed in the scope of the bimonthly visits to the farms. Deviation from reality can be quantified for the actions of the six farmers of the working group.

\section{Results}

From study of dairy farm management constraints: adjustments to be made to decision approaches

The models we have for understanding and representing a farmer's action processes apply to situations where there is a single decision-maker per holding. In the case of dairy farms of Reunion Island, the single decision-maker manages multiple and quickly accomplished technical operations. Each operation takes a short time and is performed in a day.

Previous conceptual models focused on farming systems making extensive use of machinery. In the dairy farms of Reunion Island, although technical operations are also mainly mechanised, farms where the technical operations are mostly manual are also seen; the diversity of farm practices is particularly important in this island. In all the cases, the main part of the work is done by the farmer, while some assistance is provided by household members and occasionally by trainees. Since hired labour is expensive, it is not preferred (as in many developed countries).

Table 1 presents the main constraints, concerning the realisation of biomass flow operations, expressed by the 36 farmers interviewed in the scope of the large-scale approach. These constraints are presented in priority order and they essentially concern (i) climate, (ii) forage availability and (iii) workforce.

Climatic constraints: importance of adjustments rules. Some dairy cattle-rearing areas that are located roughly between the 2000 and $4000 \mathrm{~mm}$ isohyets are particularly wet. There is a single rainy season spread over about 8 months, between October and May. Farmers are under the constraint of rainfall patterns. Rains activate weed growth in the fields and limit harvest possibilities. Therefore for the farmers 'it is difficult to foresee dates of silage making'. Owing to this fact it is not surprising to observe divergences of practices from action plans. In such cases, alternative solutions have to be activated by farmers. Date adjustments for action by farmers owing to climatic constraints have been particularly focused in this study (e.g. Table 4).

Variability in forage resources availability: adjustments to jungle with different feeds. An action plan does not consider only time characteristics of action but also includes the descriptive variables of technical operations (Which stores have to be mobilised? What is the usual modality?). For example, the plan provides different types of food rations to different animal batches, according to different practical seasons (Vayssières and Lecomte, 2006). The definition of the practical seasons by farmers is expressed as their anticipation of intra-year variations of forage availability. Forage production and supply is seasonal (sugar cane campaign for cane straw and bagasse, summer for Chloris gayana hay). Also, forage production varies also widely from year to year. It is a result of inter-year climatic variations because of the island and mountainous character of the environment. These factors make it difficult for the farmers to follow their planned rations. Adjustments of type and quantity of biomass using (e.g. feed) are also important concerns of this study (e.g. Table 5).

Time is the scarce factor: importance of arbitration rules between competing operations. During favourable weather windows, farmers have both to harvest forage and spread manure (on different fields). Hence, these technical operations can be concomitant at the farm scale. Furthermore, in these production systems, available time as the scarce factor is appreciated because of its cost and limited availability at certain periods.

Given this available time limitation, work organisation on the farms must be taken into account in technical management models for dairy farms management. We define work organisation as a farmer's plans for distribution of labour and equipment to carry out the technical operations determined by the technical management decisions taken for present on the farm (Aubry and Chatelin, 1997). Equipment constraint appears only when it is shared between farmers. Regarding the whole-farm management and in view of the severe time constraints on these farms at certain seasons, special emphasis is given on how the labour is divided among technical operations (mainly through priority rules).

Priority between technical operations: a meta-rule. Study of labour competition reveals that priority rules between technical operations are very similar from one farm to another. It can be considered as a meta-rule (Dounias et al., 2002). We propose to synthesise this priority rule in three groups of technical operations classified in priority order.

(1) 'Non deferrable and routine technical operations' are performed daily, generally at specified times in the day. Essentially it is herd management operations: milking, animal feeding, green harvest, mulching, slurry removal.

(2) 'Urgent and contextual technical operations' are performed in the day. It is all the operations that need very specific climatic conditions, cultural stage, and material availability. These are essentially forage culture management operations: ensiling, changing of pasture, manure spreading, mineral fertiliser spreading.

(3) 'Non priority technical operations' are realised in a 2-week planning horizon and these can generally be anticipated by the farmers. These include solid manure removal, buying of concentrate feed, mineral fertiliser 
and forage, buying and selling of animals and selling of solid manure.

To have the precise hierarchy between technical operations priority numbers in Table 1 may be referred. The precise hierarchy could be defined as: 'milking > animal feeding > green harvest $>$ mulching, etc.'. It illustrates, the priority rule found in the conceptual structure on the dairy farm management case, proposed in following section.

The conceptual structure: convergence between the action model and the agricultural production systems ontology The structure for action modelling (SAM), proposed in Figure 2, is based on the ontology of Martin-Clouaire and Rellier (2003). Three sub-systems (the manager, the operating system and the biophysical system) are defined. The technical operations are advocated first, then activated and finally characterised, and the characterised operations generate biomass flows in the biophysical system.

This structure is also composed as follows.

(1) Starting rules relative to both alarms and operations schedule;

(2) Feasibility rules are composed as follows.

- A priority rule that concerns solely of technical operations. It solves labour distribution when concurrence occurs. This priority rule has been dealt in the previous section.
- Feasibility conditions rules that specify if extra farm labour and equipment have to be gathered and what climatic conditions are necessary to realise the technical operation.

(3) Characterisation rules define the specification elements of the ontology, i.e. the descriptive variables of the technical operation realised: its modality and duration, the biomass quantity used, store from which it is taken, the quality of the biomass produced (if there is transformation during manipulation), and which store is replenished.

These descriptive variables of operations are the link between the decision system and the biophysical system. They specify the biotechnical characteristics of the biomass flows generated by operations.

The SAM, proposed in this study, also incorporates the concept of action model. Effectively, for each of the three types of decision rules (starting, feasibility and characterisation rules) we find both realisation and adjustment rules (see examples proposed in next section), as defined by the action model. Moreover, as discussed by Aubry et al. (1998) and Dounias et al. (2002), the structure consists of descriptive variables and decision rules. Some types of rules are common such as activation rules, arbitration rules, rules for establishing mode. Operations sequencing and fields grouping rules are not necessary in our structure because we do not model how the action plan is defined. But we model here how the action plan is put into practice or not.

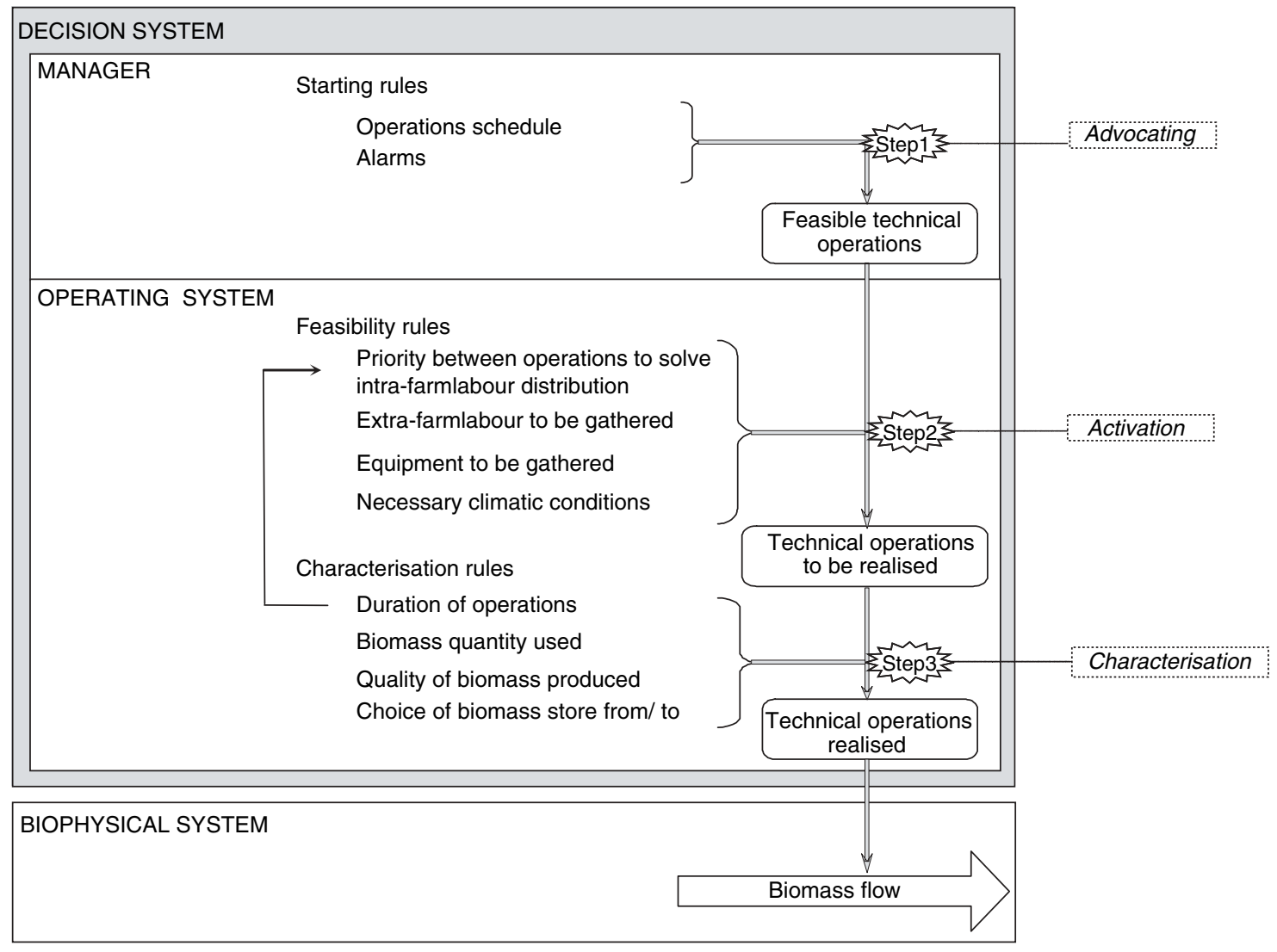

Figure 2 Representation of the structure for action modelling (SAM) applied to biomass flow operations. 
A generic structure offering a pertinent way of interpreting a farmer's actions: illustration by examples

It is a generic structure in a way that it is available for all the technical operations at the origin of biomass flows identified in dairy farms.

We illustrate here the generic nature of the SAM and its application to two operation domains that have significant consequence on biomass flows: forage harvest and animal rationing. Practices of the farmer 2 (one of the six farmers of the working group) are formally described with the conceptual structure to represent action. In Tables 2 and 3, we list and classify the different operational decision rules.

(1) Forage harvest: the first example is ensiling operation (Table 2). It is relative to a grassland field (= the operated object). This operation is exclusively advocated by alarms about the state of the grassland. The grass height is generally the indicator used by farmer 2, but in winter the percentage of plants at ear-emergence stage is more often used. The growth rate of grass is also evaluated by visual assessment of grass height about 2 months after previous harvest, if the farmer judges it insufficient the field is harvested earlier. This second type of adjustment generally occurs during a severe dry period or when a strong rain occurs just after fertilisation (leaching of mineral nutrients).

When climatic conditions and realisation constraints are satisfied the ensiling operation is directly carried out. The concurrence with other operations does not affect its activation, because it is slotted in a high level of hierarchy. In Tables 2 and 3 the priority rule defining this hierarchy is simplified from the one described above: it is applied to only three operations. The ensiling works suppose extrafarm labour, generally represented by two brothers of farmer 2, but only one brother could be sufficient. They hold their own ensiling chain and they share the harvest of the grasslands in each of their farms. It is less restricting than renting it to an enterprise. Farmer 2 explains that the main constraint is climatic: 2 days without rain are necessary to harvest a non-humid grass and to have relatively dried soils (to avoid grassland degradation). The following day, if the morning is sunny, the work can be done.

The ensiling modality and its duration are determined by the number of farmers ready to work. Generally the three brothers are present. The biomass harvested is generally all the grass present on the field at the origin of the operation. But rain can interrupt his work. In this case, the harvested area of the field is reduced. From a flow point of view, the 'store from' is the harvested field (or a part of it) and the 'store to' is a new store of round bales constituted on the field border.

(2) Animal rationing: the second example is the feeding operation of the producing cows (Table 3). Contrary to the previous example, this operation is advocated by the operations schedule. Farmer 2 plans to feed his cows once daily to avoid silage degradation (occurring if he distributed once in 2 or 3 days as done by other farmers). Feeding is one of the priority operations (with milking).
No realisation constraints and no climatic conditions exist; this operation is effectively undertaken on a daily basis. Ration distribution is generally done with a ration mixer: the silage, the cane straw, the molasses and the bigger part of the concentrate $(60 \%)$ is incorporated in the mixer. The rest of the concentrate and the hay are distributed manually. On farm observations, during the immersion, permit us to evaluate the speed at which this operation is performed. Even if some feeds are mixed and simultaneously distributed, we differentiate distribution speed for each feed, for modelling needs. It could happen that the mixer goes out of order, and then the entire ration is manually given. Concerning the quantity of biomass used, farmer 2 has one planned food ration for all the year and any adjustments are done according to forage store levels. The part generally distributed with the mixer is defined for the entire producing cows' batch (about 50 animals). The rest is individually distributed, so adjustments can be made about (i) hay if an animal has diarrhoea by improving quantities (ii) and concentrate corresponding to individual milk production (IMP). For example an animal starting its lactation with an IMP higher than $30 \mathrm{~kg} /$ day receives $15 \mathrm{~kg} / \mathrm{day}$, and an animal ending its lactation with an IMP lower than $15 \mathrm{~kg} /$ day receives $8 \mathrm{~kg} /$ day of concentrated feed. Adjustments are also realised by farmer 2 at the herd-scale if the hay store or the cane straw store is empty. If the farmer is short of hay he compensates with the cane quantities and vice versa. From a flow point of view, the stores-from are the stores of the corresponding feeds. Silage represents a particular case, where the farmer tries to reserve better quality (= 'dry' silage) to producing cows in giving less quality (= 'humid' silage) to heifers' batch. But sometimes, when humid silage stores proportion is too important, it is used in cows' ration. In this case half a round bale of humid silage is given to producing cows (replacing half a round bale of dry silage). The store-to of the biomass flow is the trough of the animal batch considered (producing cows in this case).

From operational decision rules to simulation of a farmer's actions

The different operational decision rules listed in the SAM can be converted to mathematical functions and introduced into a computer model. The SAM's pertinence to build the WFDS of a computer model that simulates a farmer's actions is here illustrated with the two operations described in the previous section.

The two operation descriptions of the previous section illustrate the importance of adjustments in the farm management. The adjustments mainly affect:

- the realisation date for outdoor operations subject to climatic uncertainty (e.g. forage harvest),

- the quantity of matter manipulated for indoor operations subject to biomass availability (e.g. animal rationing).

Therefore, we propose here to focus attention on two particular outputs of the WFDS: the dates of the ensiling works 
Table 2 Translation of discourse and practices of farmer 2 into decision rules for ensiling works

\begin{tabular}{|c|c|c|c|c|}
\hline $\begin{array}{l}\text { Decision rules } \\
\text { categories }\end{array}$ & & Descriptive variables & Realisation decision rules & Adjustment decision rules \\
\hline \multirow[t]{3}{*}{ Starting rules } & Operations schedule & & $\varnothing$ & \\
\hline & Alarms (operation a priori selected) & & If grass height $>35 \mathrm{~cm}$ (in summer) & $\begin{array}{l}\text { Or if percentage of plants at ear emergence } \\
\text { stage }>30 \% \text { (in winter) }\end{array}$ \\
\hline & & & & $\begin{array}{l}\text { Or if time from the last harvest }>2 \text { months } \\
\text { and if grass height }<25 \mathrm{~cm}\end{array}$ \\
\hline \multirow[t]{6}{*}{ Feasibility rules } & Hierarchy between operations & & Feeding $>$ ensiling $>$ spreading & \\
\hline & Extra-farm labour to be gathered & & If one or two extra-farmers (his brothers) are free & \\
\hline & Equipment to be gathered & & If two tractors (from the farm preferentially) are free & \\
\hline & & & And if the common ensiling chain is free & \\
\hline & Necessary climatic conditions & & If the beginning of the morning is sunny & \\
\hline & & & $\begin{array}{l}\text { And if two last days without rain } \\
\text { (not humid grass and dried soil) }\end{array}$ & \\
\hline \multirow[t]{9}{*}{ Characterisation rules } & & 'Modality' and Duration & $\begin{array}{l}\text { Generally 'with two extra-farmers': } \\
\text { speed } S=40 \text { round bales per } h\end{array}$ & $\begin{array}{l}\text { If not the two extra-farmers are free: 'with one } \\
\text { extra-farmers': } S=10 \text { round bales per } h\end{array}$ \\
\hline & & Biomass quantity used & $\begin{array}{l}\text { All the biomass present on the field at the beginning } \\
\text { of the action }\end{array}$ & $\begin{array}{l}\text { If interruption by rain: all the biomass } \\
\text { present on the harvested part }\end{array}$ \\
\hline & & $\begin{array}{l}\text { Quality of biomass } \\
\text { produced }\end{array}$ & Depending of the weather: & \\
\hline & & & If fine rain: dry mater percentage $(D M)=15-20 \%$ & \\
\hline & & & If cloudy weather: $\mathrm{DM}=20-30 \%$ & \\
\hline & & & If mixed sunny/cloudy weather: $\mathrm{DM}=30-40 \%$ & \\
\hline & & & If persisting sunny weather: $\mathrm{DM}=40-60 \%$ & \\
\hline & & $\begin{array}{l}\text { Choice of biomass } \\
\text { store from }\end{array}$ & The field at the origin of the action & $\begin{array}{l}\text { If interruption by rain: a part of the field at } \\
\text { the origin of the action }\end{array}$ \\
\hline & & Choice of biomass store to & A new store of round bales on the field border & \\
\hline
\end{tabular}


Table 3 Translation of the discourse and the practices of farmer 2 into decision rules for feeding of producing dairy cows

\begin{tabular}{|c|c|c|c|c|}
\hline $\begin{array}{l}\text { Decision } \\
\text { rules categories }\end{array}$ & & Descriptive variables & Realisation decision rules & Adjustment decision rules \\
\hline Starting rules & $\begin{array}{l}\text { Operations schedule (operation a priori selected) } \\
\text { Alarms }\end{array}$ & & one time per day & \\
\hline Feasibility rules & $\begin{array}{l}\text { Hierarchy between operations } \\
\text { Extra-farm labour to be gathered } \\
\text { Equipment to be gathered } \\
\text { Necessary climatic conditions }\end{array}$ & & $\begin{array}{l}\text { Feeding }>\text { ensiling }>\text { spreading } \\
\varnothing \\
\varnothing \\
\varnothing\end{array}$ & \\
\hline \multirow[t]{5}{*}{ Characterisation rules } & & 'Modality' and Duration & $\begin{array}{l}\text { Generally 'Main part with the mixer... } \\
\text { - silage: speed } S=3 \text { round bales } / \mathrm{h} \\
\text { - cane straw: } S=4 \text { sheaves per h } \\
\text { - molasses: } S=200 \mathrm{l} / \mathrm{h} \\
\text { - concentrated feed: } S=1200 \mathrm{~kg} / \mathrm{h} \\
\text { and the rest manually' } \\
\text { - hay and concentrated feed: } S=400 \mathrm{~kg} / \mathrm{h}\end{array}$ & $\begin{array}{l}\text { If the mixer is out of order 'all manually' } \\
\text { - silage: } S=2 \text { round bales per } h \\
\text { - cane straw: } S=2 \text { sheaves per } h \\
\text { - molasses: } S=120 \mathrm{l} / \mathrm{h} \text {, etc. }\end{array}$ \\
\hline & & Biomass quantity used & $\begin{array}{l}\text { Generally } \\
\text { For } 50 \text { animals and per day: } \\
\text { - 'dry' silage: } 1.5 \text { round bale } \\
\text { - cane straw: } 1 / 3 \text { sheaf } \\
\text { - bagasse: } 0 \mathrm{~kg} \\
\text { - molasses: } 30 \text { I } \\
\text { Per animal and per day: } \\
\text { - hay: } 1 \mathrm{~kg} \text { - } \\
\text { concentrated feed: } 14 \mathrm{~kg} \text { (B } 80: 55 \% \text {, } \\
\quad \text { M } 45: 30 \% \text {, Pulco: } 15 \%)\end{array}$ & $\begin{array}{l}\text { For all the herd } \\
\text { If no hay in store: improve cane straw to } 1 / 2 \text { sheaf and bagasse } \\
\text { to } 50 \mathrm{~kg} \text { (hay: } 0 \mathrm{~kg} \text { ) } \\
\text { If no hay and no cane straw in store: improve bagasse to } 75 \mathrm{~kg} \\
\text { (hay and cane straw: } 0 \mathrm{~kg} \text { ) } \\
\text { If no cane straw: improve bagasse to } 50 \mathrm{~kg} \text { (cane straw: } 0 \mathrm{~kg} \text { ) } \\
\text { If no cane straw and no bagasse in store: improve hay to } \\
1.5 \mathrm{~kg} \text { per animal (cane straw and bagasse: } 0 \mathrm{~kg} \text { ) } \\
\text { Individually } \\
\text { If animal have diarrhoea: improve hay to } 1.5 \mathrm{~kg} \text { per animal } \\
\text { If individual milk production (IMP) excess } 30 \mathrm{l} / \mathrm{day} \text { : improve } \\
\text { concentrated feed to } 15 \mathrm{~kg} / \text { animal (increasing Pulco's proportion) } \\
\text { If } 20<\mathrm{IMP}<25 \mathrm{I} / \text { day: reduce concentrated feed to } \\
12 \mathrm{~kg} \text { (keeping the proportion) } \\
\text { If } 15<\text { IMP }<=20 \mathrm{I} / \mathrm{day}: \text { reduce concentrated feed to } \\
10 \mathrm{~kg} \text { (keeping the proportion) } \\
\text { If IMP }<=15 \mathrm{I} / \mathrm{day} \text { : reduce concentrated feed to } 8 \mathrm{~kg} \\
\text { (keeping the proportion) }\end{array}$ \\
\hline & & Quality of biomass produced & $\varnothing$ & \\
\hline & & Choice of biomass store from & $\begin{array}{l}\text { The feed store corresponding to the } \\
\text { feed category (e.g. hay) }\end{array}$ & \\
\hline & & Choice of biomass store to & The trough of producing cows & \\
\hline
\end{tabular}


and the composition of the producing cows' ration. We continue to discuss the practices of farmer 2 in 2005 to present the entire process of converting the discourse of farmer 2 into a computer model that simulates his management actions.

From a mathematical point of view, actions and conditions are represented as a dynamic process by a binary function of time. For actions: a value of 1 represents that the action is in course, 0 it is not. For conditions: a value of 1 signifies that the condition is verified; 0 it is not. Only the conditions that have effective influence on the realisation of actions for the 2005 year are presented in Figure 3.

Concerning the ensiling operation, starting and feasibility rules of Table 2 can be converted into conditions used in a mathematical function that determinates if the ensiling works are done or not:
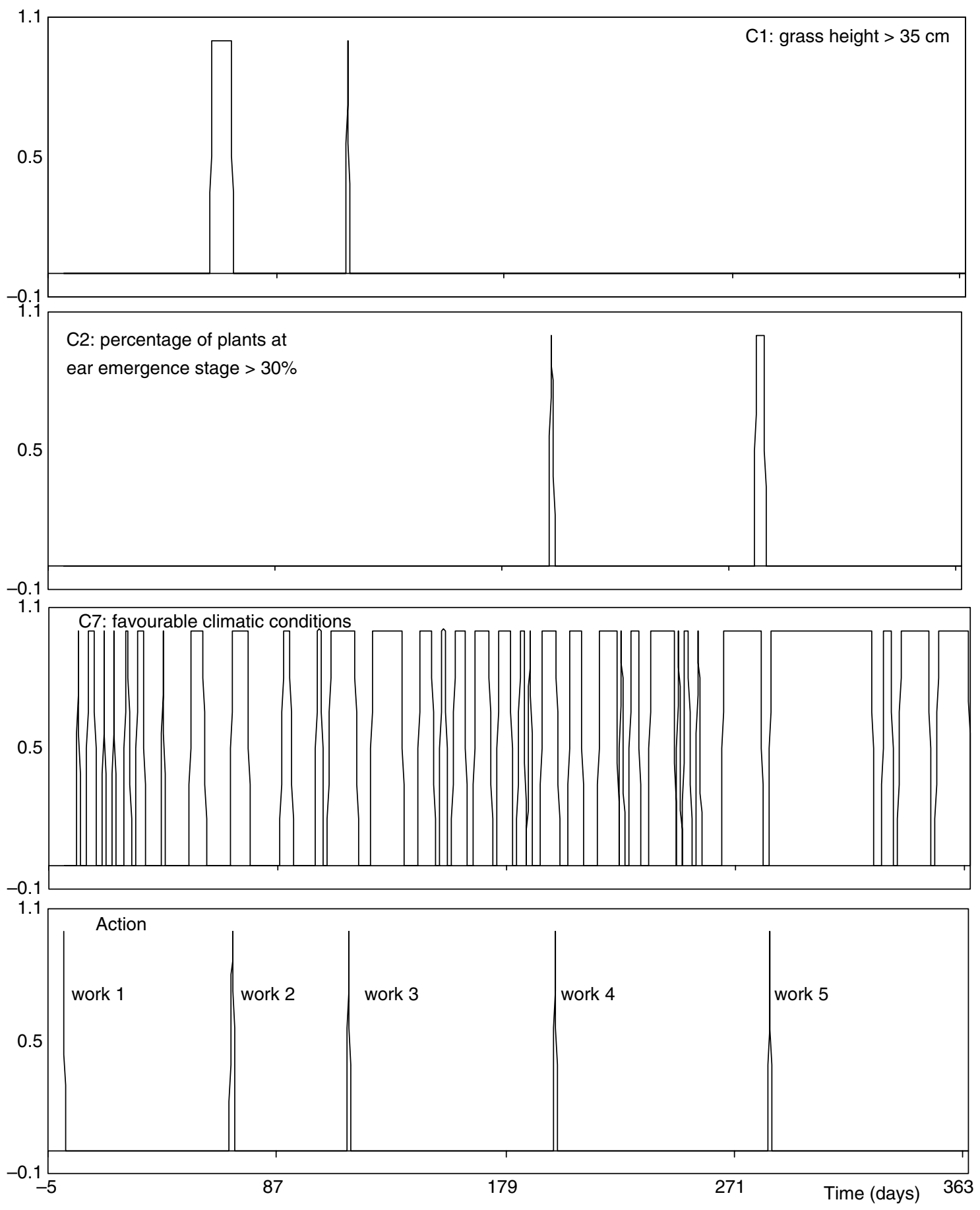

Figure 3 Ensiling works: conditions status and action dates simulated by the whole farm model - WFM - ('SAM actions', field 2, farm 2 for 2005). 


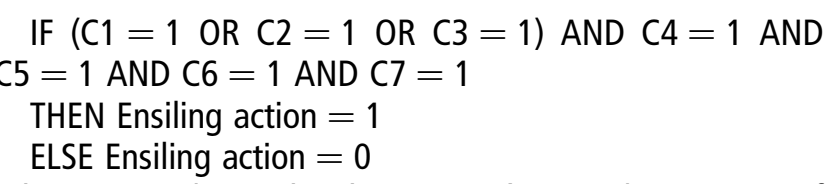
Where: C1 is 'Grass height $>35 \mathrm{~cm}$ ', C2 is 'Percentage of plants at ear emergence stage $>30 \%$ ', C3 is 'Time from the last harvest $>2$ months and grass height $<25 \mathrm{~cm}^{\prime}$, etc. C7 is 'The beginning of the morning is sunny and two last days without rain'.

The outputs of the model are presented in Figure 3. The model represents that the indicator used by farmer 2 to start ensiling works depends on the season: the grass height in summer (ensiling works 1 to 3 ) and the plant maturity in winter (ensiling works 4 and 5). It also represents that climatic conditions are responsible for any delay in ensiling works (ensiling works 2 and 5).

Concerning the feeding operation, characterisation rules of Table 3 have also been converted into mathematical functions. For example, the hay quantity distributed to cows (HQ) is calculated as the flowing equation:

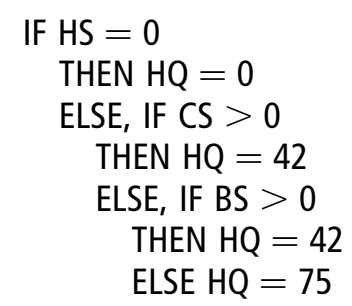

Where:

HS, CS and BS are the levels of the hay store, the sugar cane straw store and the bagasse store (in $\mathrm{kg}$ ) respectively. $\mathrm{HQ}, \mathrm{CQ}$ and $\mathrm{BQ}$ are the quantities of hay, sugar cane straw and bagasse distributed to producing cows respectively (in $\mathrm{kg} /$ day or in sheaves per day).

The outputs of the model are presented in Figure 4. The model illustrates the big variability of forages stores levels over the year and its consequences on the ration composition. For example, for farmer 2, hay unavailability (days 1 to 152,247 to 258 , and 280 to 285 ) is represented as an important source of variation of the ration composition. Only the forage part of the ration is presented here. The transition period, just before the beginning of the sugarcane campaign, is also critical. This example shows that in some years cane straw stores are insufficient to continue with the normal rations until the provisioning of the sugar cane straw after just the transition period. Therefore, a ration composition adjustment becomes necessary (days 236 to 239).

\section{Discussion}

Validation and co-products of the action modelling Quantitative validation of the methodology. As discussed above, this section compares the outputs of two simulation options of the WFM: (i) if actions are derived from the action plan they are called 'planned actions', and (ii) if from the operation decision rules listed in the SAM, they are called
'SAM actions'. The two types of simulated actions are compared with 'effective actions' observed in the scope of the bimonthly visits to the farms. Continuing with the two illustrations of operations in the results section, we propose here to compare (a) the dates of simulated ensiling works to the effective dates (Figure 5) and (b) the nature of the food ration simulated to rations effectively distributed to dairy cows (Figure 6). Schedules within a week time-step are used for this comparison. Two error indicators can be derived from these simplified representations: (a) the percentage of ensiling works if the simulated date differs by more than 2 weeks from the effective date and (b) the percentage of weeks if the simulated ration is different to the effective ration. Figures 5 and 6 illustrate that SAM actions are more realistic than planned actions. For example, the error on ensiling dates is reduced from 14.8 days $(+I-11)$ to 6.2 days $(+I-6)$.

Improving the realism of the action increases the precision of the biotechnical indicators calculated by the WFM. To illustrate this point Figure 7 shows the biomass of green forage present on a field in farm 2 as a result of two harvest practices (planned and SAM harvests). The action plan simulation generates early harvest of the forage (meaning under estimating the quantity harvested per ensiling works) and overestimates the annual yields (six harvests per year versus five harvests per year for the SAM and the effective practices). The error due to the simulation (overestimates and underestimates) on quantity harvested per ensiling works is reduced with the SAM actions: the error is reduced from 28.5 to $12.0 \%$.

Figure 8 represents dynamically the store level of sugarcane straw as a result of two rationing practices (planned and SAM rationing). The action plan tendency is an overvaluation of store levels because of an undervaluation of the use of co-products of sugar cane to feed animals. Using the SAM to simulate actions decreases the error of stores management models from 20.5 to $7.5 \%$.

To summarise, the SAM and the corresponding methodology (including immersion) increase the realism in comparison to more classical methodologies (rapid appraisals) and resulting models that simulate actions from the action plan.

Qualitative validation of the SAM. Three forms of validation have been combined.

(1) Validation at the farm level. We used the SAM to formalise and represent various actions: all the 19 technical operations that generate biomass flows were studied. Hence this could be considered as a generic structure. Two radically different operations have been taken as illustrative cases for the study, and the validation approach that can be extended to the remaining operations.

(2) Validation at the working group level. As discussed by Fountas et al. (2006), we notice that the participatory method offers certain form of validation by leading to refinement and modifications of the SAM. As explained above, farmers of the working group were involved 

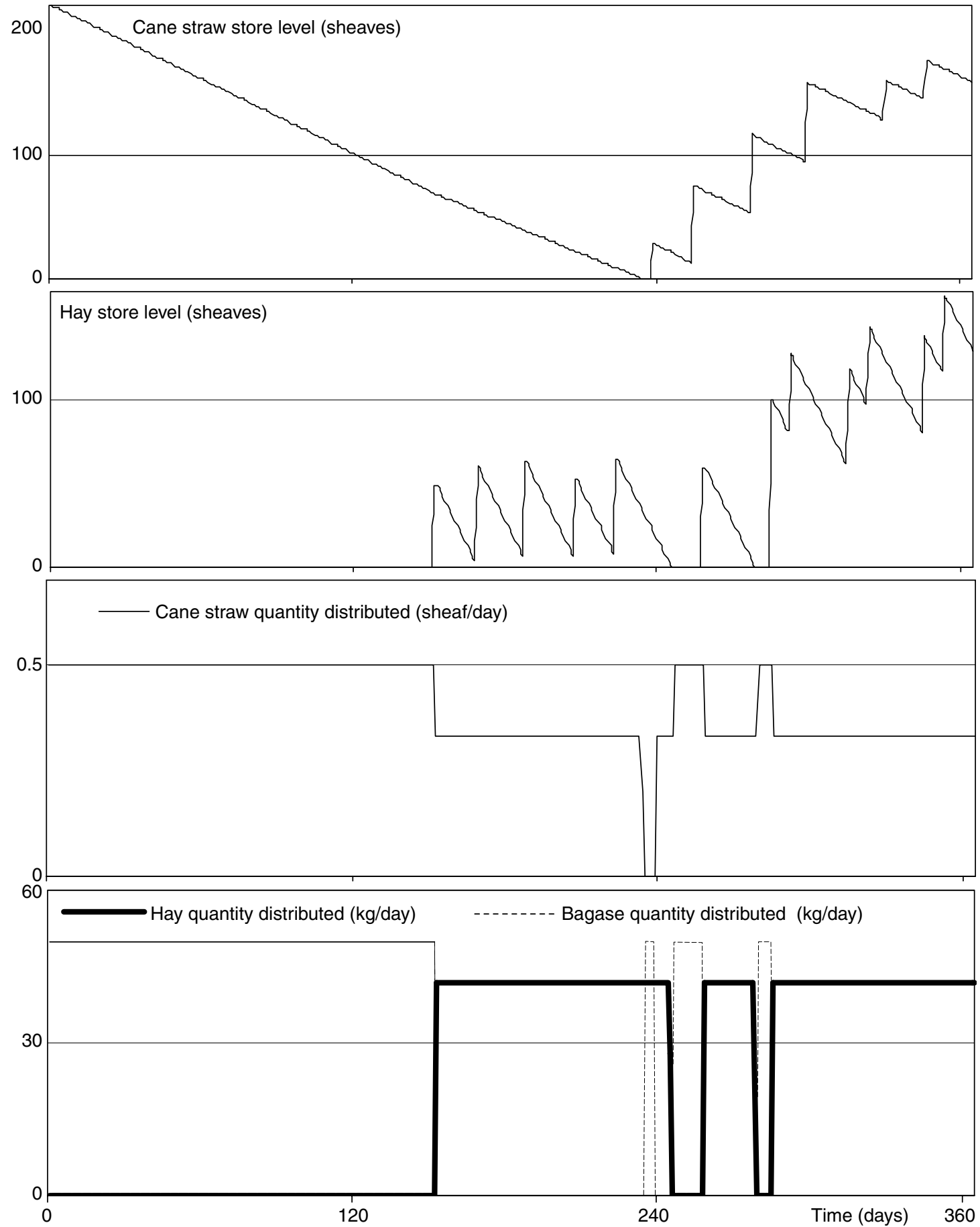

Figure 4 Forage stores level and ration composition of producing cows simulated by the WFM ('SAM actions', farm 2 for 2005).

\begin{tabular}{|c|c|c|c|c|c|c|c|c|c|c|c|c|c|}
\hline Season & \multicolumn{4}{|c|}{ Summer } & \multicolumn{5}{|c|}{ Winter } & \multicolumn{3}{|c|}{ Summer } & \\
\hline Month & January & February & March & April & May & June & July & August & September & October & November & December & Error $^{\dagger}$ \\
\hline $\begin{array}{l}\text { Effective } \\
\text { actions }\end{array}$ & & & & & & & & & & & & & - \\
\hline $\begin{array}{l}\text { Planned } \\
\text { actions }\end{array}$ & & & & & & & & & & & & & $80 \%$ \\
\hline $\begin{array}{l}\text { SAM } \\
\text { actions }\end{array}$ & & & & & & & & & & & & & $20 \%$ \\
\hline
\end{tabular}

$\dagger$ The error represents the percentage of ensiling works if the simulated date differs by more than two weeks from the effective dates.

Ensiling work.

Figure 5 Temporal repartition of the ensiling works: simulated actions compared with effective actions (field 2, farm 2 for 2005). 


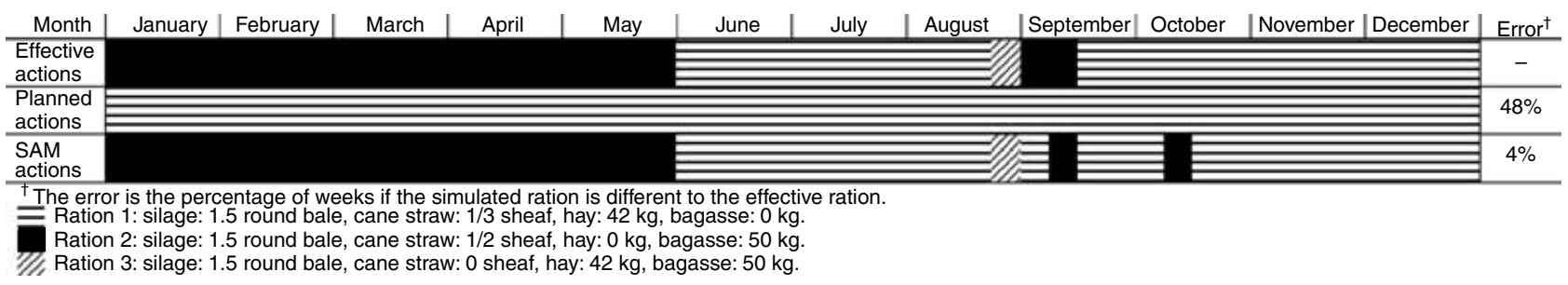

Figure 6 Composition of the food ration (forage part): simulated actions compared with effective actions (50 producing cows, farm 2 for 2005).

in individual and collective validations. Since decision rules are researchers' mental constructions, it became important for us to validate them from farmers' expertise. We have coupled three types of validation contexts: individual feed-backs in the scene of the bimonthly visits, collective feed-backs and collective work during meetings. The SAM was presented to the six farmers under the form of a question series corresponding to the different decision rules. The farmers' reactions were 'all the questions that we have to consider are listed... some of them are momentary... but those questions do not come up all the time...'. Discussions with farmers about this conceptual model have shown that this three-step structure (the SAM) has a certain similarity with real decision processes of farmers. The farmer, starting his days' work, lists the technical operations he has to perform in the day, he selects those he can realise considering his means of action ( $=$ resources), then he carries out the operations that have been selected.

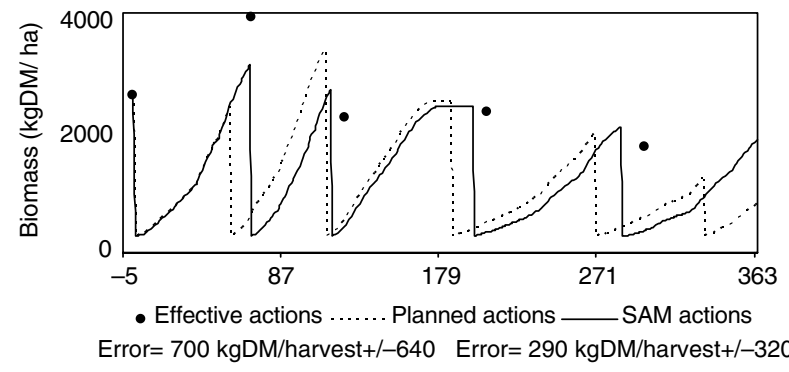

Figure 7 Green forage on field simulated by the WFM: compared with biomass simulated from 'planned actions' and from 'SAM actions' to 'effective actions' (field 2, farm 2 for 2005).

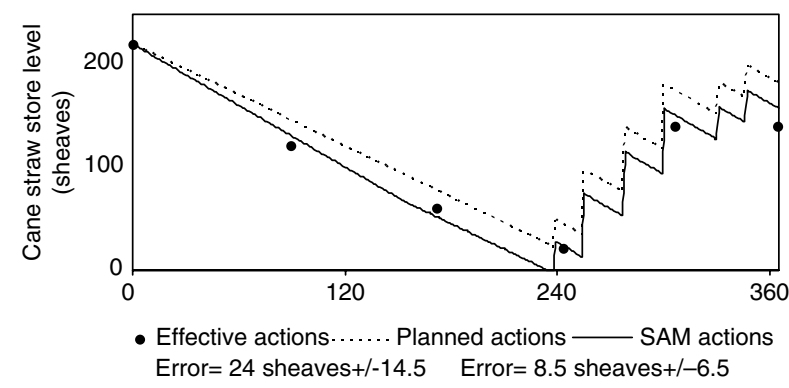

Figure 8 Forage store level simulated by the WFM: compared with biomass simulated from 'planned actions' and from 'SAM actions' to 'effective actions' (sugar cane straw store, farm 2 for 2005).
(3) Validation done at the regional level. It concerned the 36 farms of the typology group: $37 \%$ of the farms of the dairy sector. It was necessary to test the SAM with farmers not involved in the conceptualisation of the structure. The SAM has been applied to formalise the 36 dairy farmers' actions of farm management, their work organisation and to understand their strategies. This application has constituted the base of the typology of practices combination (Vayssières et al., 2006). Additional research is required to test the validity of the SAM proposed in this study in dairy farms of other countries or moreover to study other production systems.

\section{Crossing planned action and situated action theories}

We have already seen that conceptual elements of both the action model concept and the ontology of agricultural production systems are combined in the structure proposed. Several previous studies applying the action model insist on planning of decisions and actions. However, as this study has shown, the action plan is scarcely followed because of diverse reasons (constraints listed in Table 1) and that adjustment rules are numerous.

Another theory exists, generally presented in opposition to 'planned action' and called 'situated action'. This theory presents action as a result of decisions mainly guided by contextual aspects of the farmer's environment and not only oriented by general objectives. In situated action (Suchman, 1987), the emphasis is on interaction between the agents and their environment. The notions of 'plan' and 'objective', which are the bases of the planned action theory (the problem-solving approach), are deemed irrelevant to simulate action in people's practice. A plan is viewed as a resource for action, not as its mere determinant, and 'motive' is substituted for 'objective' (Suchman, 1987; Clancey, 2002).

This second theory can explain observations of Fountas et al. (2006), noting that some farmers are more instinctive than others which is also noted in dairy farmers of Reunion. In certain cases, it was difficult to construct the action plan of the farmers with them, as they did not have a plan of their farm management at a yearly time horizon but at a 2-week time horizon. In spite of this drawback, the way they manage their farms was also successfully developed with the SAM. For those 'intuitive farmers', the majority of technical operations are initiated by alarms contrary to 'planning farmers', in which technical operations are more often initiated by operation schedules. The SAM 
approach has the advantage of considering both planned action and situated action theories. Studies on operational decisions, like the one presented in this article, seem to offer a bridge between those two theories and could help to define a modelling ontology of action (Guerrin, 2005).

Co-products of action modelling: a better comprehension of farmers' logic of farm management

Other results of this study have not been reported in this article and will appear as separate publications. However, we list here some co-products of action modelling.

The primary aim of this study was to explain (with simulation) farming practices and difference of achievements between years for the same farmer to identify realisation and adjustment rules. As discussed by Aubry et al. (1998) and Dounias et al. (2002), this study focused on identifying key management factors and to understanding variability of practices between different farmers in a same year. We have represented the strategy diversity of dairy farmers as the typology of practices combination (Vayssières et al., 2006). We have also identified the indicators used by farmers to manage their farm and we have observed that they are not the same as those proposed by researchers. Taking the grasslands management example was the occasion to defend search of common indicators (Vayssières et al., 2005).

These studies on technical operations were also an opportunity to synthesise knowledge about complex agricultural production systems and to move to other decision levels: tactical (the action plan) and strategic decisions. In particular, we have identified numerous factors that determine a farmer's strategy definition: biophysical (climate, soil characteristics) and socio-economic (degree of geographical isolation, concentration of dairy farms) environmental factors, exploitation structure (equipment, land), technical references of the farmer and the objectives of the household. These two last components appear particularly important in our study case (Vayssières, 2004). They are based on a set of experiences, level of training, education and cultural aspects. They have important consequences on time that the farmer is ready to invest in the management of his farm (between 35 and $75 \mathrm{~h} /$ week), and on the strategic technical choices. In the WFDM derived from the SAM factors which are not purely technical (e.g. cultural) are taken account via the available time to realise technical operations. For example, farmers participating in religious/ cultural events lose a part of their available time at certain periods. The SAM offers the possibility to also consider current life events, like death in the family/friends, sickness or wedding, by decreasing momentarily the available time, and to represent their consequences on technical actions. The effect on actions is indirect (via the available time) and consequently beyond the scope of this article.

Moreover, the methodology proposed in this study presents an opportunity to determine the nature of technical references and to point lack of information and knowledge. Those two observations are respectively supported by Sebil- lotte and Soler (1988), Barbier and Mouret (2000) and Fountas et al. (2006). A better understanding of a farmer's knowledge could help to define more adapted management indicators, and to predict innovation adoption or rejection.

To synthesise, action modelling gave us a larger expertise of the production system than expected.

\section{Conclusion}

The results of this study are two-fold. First, a multi-step and multi-tool methodology has been developed for systematically collecting information from farmers to describe their action-making process. The methodology combines detailed and large approaches (36 farms). The detailed approach concerns a work group of six farmers involved in the whole-farm model construction. These real case studies are based on three complementary methods of inquiry: immersion, visits and meetings.

Second, a three-step structure for action modelling, the SAM, has been presented. It describes the successive intervention of different types of operational decision rules and it solves competition for resources between technical operations. The importance of this competition would not be revealed if the whole-farm management was not considered. The SAM also helps to define the guidelines of the inquiries, making sure factors that could influence decisions are not forgotten. The methodology and the conceptual structure to represent action are thus particularly linked.

The hypothesis that farmers plan their decisions is verified as regards the technical management of forage crops and dairy cattle. But regarding how the action plan is executed or not has shown the importance of necessary adjustments with reference to climatic uncertainty, forage abundance, labour and equipment availability. This wholefarm study shows that technical management of dairy farms is not the sum of the technical decisions taken for each field, for each animal batch or for each technical operation. The farmer manages the farm shift as a whole and it is the decisions made at this level that determine how each individual field or animal batch is managed and how each technical operation is conducted.

To approach the research objectives by technical operations was not only a way to better understand managing interactions within the agricultural system but, technical operations and their descriptive variables, specifying the biophysical effects of operations (flows nature and stores level in this case), are the link between the decision system and the biophysical system.

The methodology and representation structure presented in this paper could possibly be extrapolated to study other agricultural production systems because, firstly the structure has been applied in dairy farms from concepts developed and mainly applied to crop farms. Secondly, the dairy farm is a particularly complex system, comprising both animal and crop management. Thirdly, we have studied a very large range of technical operations: crop fertilising and harvest, cattle feeding, replacement and culling, manure conversion and spreading. Finally, the strategies observed are diverse: 
we encounter strategies existing as in developing countries (e.g. based on manual green harvest of forage), as in developed countries (e.g. based on mechanised grass ensiling in wrapped bales). Therefore, this 'action modelling approach' has to be tested on other crop-livestock systems to build computer simulators of practices and better to understand Research-Development programs failures and successes.

\section{Acknowledgements}

We express our gratitude to Jean-Pascal Deurveilher, Etienne Vitry, Jeannick Marianne, Jean-Luxène Padre, Pierre-André Gérard and Gervais Hoarau, the farmers of the working group, for their co-operation during the 3 years of the study, and their involvement in the practices study. They have generously allocated a significant amount of time to describe their practices and validate the proposed structure on their farms. We are also grateful to Roger Martin-Clouaire and Jean-Pierre Rellier for their training about their ontology.

\section{References}

Alary V, Messad S, Taché C and Tillard E 2002. Approche de la diversité des systèmes d'élevage laitiers à La Réunion. Revue d'Elevage et de Médecine Vétérinaire des Pays Tropicaux 55, 285-297.

Attonaty JM, Chatelin MH and Garcia F 1999. Interactive simulation modelling in farm decision-making. Computers and Electronics in Agriculture 22, 157-170.

Attonaty JM, Chatelin MH and Mousset J 1993. A Decision Support System based on farmer's knowledge to assess him in decision making about work organisation and long term evolution. Proceedings of the international seminar of CIGR models computer programs and expert systems for agricultural mechanization, Florenza, Italy, 1-2 October, pp. 8-22.

Aubry C 2000. Modélisation de la gestion de production dans l'exploitation agricole. Revue Française de Gestion 129, 32-46.

Aubry C and Chatelin MH 1997. Framer's technical decisions representation and decision support. Proceedings of the INRA-KCW workshop on decision support systems, Laon, France, 22-23 October, pp. 65-71.

Aubry C, Papy F and Capillon A 1998. Modelling decision-making processes for annual crop management. Agricultural Systems 56(1), 45-65.

Aubry C, Paillat JM and Guerrin F 2006. A conceptual representation of animal waste management at the farm scale: the case of the Reunion Island. Agricultural Systems 88, 294-315.

Barbet-Massin V, Grimaud P, Michon A and Thomas P 2004. Guide technique pour la création, la gestion et la valorisation des prairies à la Réunion. UAFP - CIRAD Pôle Elevage, la Réunion, France.

Barbier JM and Mouret JC 2000. Reconsidérer les formes d'appui aux agriculteurs. Pour une agronomie de l'exploitation agricole. FaçSADe 5. INRA - SAD editions, France.

Becker H 1963. Outsiders (French translation: 1985). Éditions Métailié, Paris, France.

Bellon S, Lescouret F and Calmet JP 2001. Characterisation of apple orchard management system in a French mediterranean vulnerable zone. Agronomie 21, 203-213.

Capillon A 1986. A classification of farming systems, preliminary to an extension program. Proceedings of the international symposium on farming systems research and extension. Kansas State University, Manhatan, USA, pp. 219-235.

Cerf M, Papy F, Aubry C and Meynard JM 1990. De l'étude des pratiques à I'aide à la décision: l'exemple du système fourrager. In Modélisation Systémique et Systèmes Agraires (ed. J Brossier, B Vissac and JL Lemoigne), pp. 181-199. INRA, Paris, France.

Clancey W 2002. Simulating activities: relating motives, deliberation, and attentive coordination. Cognitive Systems Research 3, 471-499.

Collinson M 1983. Farm management in peasant agriculture. Westview Press, Boulder, Colorado, USA.
Cros MJ, Duru M, Garcia F and Martin-Clouaire R 2001. Simulating rotational grazing management. Environment International 27, 139-145.

Dodier N 1995. Les hommes et les machines. La conscience collective dans les sociétés technitisées. Éditions Métailié, Paris, France.

Dounias I, Aubry C and Capillon A 2002. Decision-making processes for crop management on African farms. Modelling from the case study of cotton crops in northern Cameroon. Agricultural Systems 73, 233-260.

Duru M, Papy F and Soler LG 1988. Le concept de modèle général et l'analyse du fonctionnement de l'exploitation agricole. Comptes Rendus de l'Académie d'Agriculture de France 74, 81-93.

Duru M, Gibon A and Osty PL 1990. De l'étude des pratiques à l'aide à la décision: l'exemple du système fourrager. In Modélisation systémique et systèmes agraires (ed. J Brossier, B Vissac and JL Lemoigne), pp. 159-179. INRA, Paris, France.

Fox DG, Tedeschi LO, Tylutki TP, Russell JB, Van Amburgh ME, Chase LE, Pell AN and Overton TR 2004. The Cornell net carbohydrate and protein system model for evaluating herd nutrition and nutrient excretion. Animal Feed Science and Technology 112, 29-78.

Fountas S, Wulfsohn D, Blackmore BS, Jacobsen HL and Pedersen SM 2006. A model of decision-making and information-intensive agriculture. Agricultural Systems 87, 192-210.

Gibbon D 1994. Farming systems research/ extension: background concepts, experience and networking. In Rural and farming systems analysis, European perspectives (ed. JB Dent and MJ McGregor), pp. 3-18. CAB International, Edinburgh, UK.

Guerrin F 2005. Simulation of action in production systems. Proceedings of the international congress on modelling and simulation, MODSIM, Melbourne, Australia, 12-15 December, pp. 210-216.

Jarrige R 1988. Alimentation des bovins, ovins, caprins, 476 pp. Ouvrage collectif. INRA, Paris, France.

Lawas CM and Luning HA 1996. Farmer's knowledge and GIS. Indigenous Knowledge and Development monitor 4, 8-11.

Le Gal PY and Papy F 1998. Co-ordination processes in a collectively managed cropping system: double cropping of irrigated rice in Senegal. Agricultural Systems 57, 135-159.

McCown RL 2002. Changing systems for supporting farmer's decisions: problems, paradigms and prospects. Agricultural systems 74, 179-220.

Martin-Clouaire R and Rellier JP 2003. Fondements ontologiques des systèmes pilotés. INRA UBIA, Castanet Tolosan, France.

Martin-Clouaire R and Rellier JP 2000. Modeling needs in agricultural decision support systems. Proceedings of the CIGR world congress, Tsukuba, Japon, 29 November - 01 December.

Papy F 1994. Working knowledge concerning technical systems and decision support. In Rural and farming system analysis. European perspectives (ed JB Dent and MJ McGregor), pp. 222-235. CAB International, Edinburgh, UK.

Papy F and Mousset J 1992. Vers une communication entre savoirs théorique et pratique (intérêt d'un logiciel de simulation). Comptes rendus du congrès international d'informatique agricole «I'informatique agricole en quête d'utilisateurs ", Versailles, France, 01-03 Juin, pp. 177-180.

Ruthenberg $H$ 1980. Farming systems in the tropics, third edition. Oxford Science Publications, Oxford, UK.

Sebillotte M 1979. Analyse du fonctionnement des exploitations agricoles. Trajectoire et typologie. Eléments pour une problématique de recherche sur les systèmes agraires et le développement. Comptes rendus de l'assemblée constitutive du département SAD, Toulouse, 20 November, pp. 20-30.

Sebillotte M 1987. Du champ cultivé aux pratiques des agriculteurs. Réflexion sur l'agronomie actuelle. Comptes Rendus de l'Académie d'Agriculture de France 73(8), 69-81.

Sebillotte M and Soler LG 1988. Le concept de modèle général et la compréhension du comportement de l'agriculteur. Comptes Rendus de l'Académie d'Agriculture de France 74(4), 59-70.

Sebillotte M and Soler LG 1990. Les processus de décision des agriculteurs. Acquis et questions vives. In Modélisation systémique et systèmes agraires (ed. J Brossier, B Vissac and JL Lemoigne), pp. 88-102. INRA, Paris, France.

Spedding CRW 1975. The study of agricultural systems. In Study of Agricultural Systems (ed. GE Dalton), pp. 3-19. Applied Science Publishers, London, UK. 
Suchman LA 1987. Plans and situated actions: the problem of human-machine communication. Cambridge University Press, New York, USA.

Sumberg J 2002. Livestock nutrition and foodstuff research in Africa: when is a nutritional constraint not a priority research problem? Animal Science 75, 332-338.

Thornton PK and Herrero M 2001. Integrated crop-livestock simulation models for scenario analysis and impact assessment. Agricultural Systems 70, 581-602.

Uschold M, King M, Moralee $S$ and Zorgios $Y$ 1997. The enterprise ontology. The Knowledge Engineering Review 13, 71-88.

Vayssières J 2004. L'appréhension des pratiques décisionnelles d'éleveurs par enquêtes-immersion: cas des activités à l'origine de flux d'azote en exploitations bovines laitières à la Réunion. Mémoire de DEA EMTS, INA-PG, Paris.

Vayssières J, Guerrin F, Paillat JM, Martin-Clouaire R and Rellier JP 2003. Modélisation conceptuelle de la gestion des flux d'azote en élevage bovin laitier à la Réunion. Proceedings of the regional interdisciplinary symposium on 'Ruminants farming and use of livestock products promotion', St Denis, Réunion, 10-13 June, p. 11.
Vayssières J, Guerrin F, Paillat JM, Martin-Clouaire R, Rellier JP and Lecomte P 2004. Modélisation conceptuelle des flux d'azote en exploitation d'élevage bovin laitier à la Réunion. Rapport CIRAD-TERA n¹5/04, la Réunion.

Vayssières J and Lecomte P 2006. La place du risque dans l'action: le cas de la gestion des stocks d'aliments en élevage bovin laitier à la Réunion. Proceedings of the international workshop "modelling environmental risk in the context of environmental, social and economic sustainability: with reference to dairy sector in la Reunion", St Pierre, Réunion, 12-16 June, pp. 53-60.

Vayssières J, Lecomte P and Gousseff M 2005. Modéliser les flux à l'échelle de l'exploitation pour accompagner les éleveurs dans la gestion de leurs prairies. Proceedings of the international symposium 'Outils pour la gestion des prairies naturelles'. VISTA UE Project, Toulouse, France, 6-8 July.

Vayssières J, Lecomte $P$, Guerrin $F$, Bocquier $F$ and Verdet $C$ 2006. Explaining the diversity of environmental performances according to a typology of farming practices combinations: the case of the dairy cattle breeding in Reunion Island. Proceedings (Vol. II) of the 12th RAMIRAN international conference "Technology for recycling of manure and organic residues in a whole-farm perspective", Aarhus, Denmark, 11-13 September, pp. 57-60. 